ISSN = 1980-993X - doi:10.4136/1980-993X
www.ambi-agua.net
E-mail: ambi-agua@agro.unitau.br
Tel.: (12) 3631-8004

\title{
Evaluation of airborne particulate matter pollution in Kenitra City, Morocco
}

\author{
doi: 10.4136/ambi-agua.1042 \\ Mounia Tahri $^{1 *}$; Moussa Bounakhla ${ }^{1}$; Mustapha Zghaïd ${ }^{2}$; Yves Noack ${ }^{3}$; \\ Fouad Benyaïch ${ }^{2}$; Abdelfettah Benchrif ${ }^{1}$ \\ ${ }^{1}$ National Center of Energy. Sciences and Nuclear Techniques (CNESTEN), \\ DASTE Department, Unity of Pollution and Geochemistry, Rabat, Morocco \\ ${ }^{2}$ Department of Physics. Faculty of Sciences. University Moulay Ismail, Meknes, Morocco \\ ${ }^{3}$ CEREGE. Aix-Marseille University, CNRS IRD, CdF - BP 80 - 13545 \\ AIX en Provence Cedex 4 - France \\ *Autor correspondente: e-mails: tahri.mounia@gmail.com, \\ moussabounakhla@yahoo.fr, zghaid_mustapha@yahoo.fr, \\ noack@cerege.fr, benyaichf@mymail.indstate.edu, \\ abenchrif@gmail.com
}

\section{ABSTRACT}

Two size fractions of atmospheric particulate matter $<2.5 \mu \mathrm{m}$ and $2.5-10 \mu \mathrm{m}$ were collected in Kenitra City from February 2007 to February 2008. The sampling was done using a Gent Stacked sampler on nuclepore polycarbonate filters and the collected filters were analyzed using Total Reflection X-Ray Fluorescence (TXRF) and Atomic Absorption Spectroscopy (AAS). The particulate matter trends show higher concentrations during the summer as compared to other seasons. The highest concentrations were obtained for $\mathrm{Ca}$ in coarse particles and Fe for fine particles. However, the lowest concentrations were observed for $\mathrm{Cd}$ in both particulate sizes. The principal component analysis (PCA) based on multivariate study enabled the identification of soil, road dust and traffic emissions as common sources for coarse and fine particles.

Keywords: X-ray fluorescence, cluster analysis, principal component analysis.

\section{Avaliação da poluição de material particulado de aviação em Kenitra, Marrocos}

\section{RESUMO}

Duas frações de tamanhos $<2,5 \mu \mathrm{m}$ e 2,5-10 $\mu \mathrm{m}$ de material particulado atmosférico foram coletadas na cidade de Kenitra de fevereiro de 2007 a fevereiro de 2008. A amostragem foi feita utilizando-se um amostrador de Gent empilhados em filtros de policarbonato Nuclepore e os filtros foram analisados para os elementos de reflexão total usando fluorescência de raios X (TXRF) e Espectroscopia de Absorção Atômica (AAS). As partículas tiveram tendência de apresentar maior concentração durante a temporada de verão em comparação com outras estações. As maiores concentrações de partículas grossas foram de $\mathrm{Ca}$ e de partículas finas de Fe. No entanto, as concentrações mais baixas foram observadas para $\mathrm{o}$ $\mathrm{Cd}$ em ambas as fracções de tamanho. A análise de componentes principais (ACP) com base na análise multivariada permitiu a identificação de emissões do solo, de poeira de estrada, e do tráfego como fontes comuns de partículas grossas e finas.

Palavras-chave: Fluorescência de raios X, análise de agrupamento, componentes principais. 


\section{INTRODUCTION}

Air pollution has become a matter of global concern because of its impact on human health and environmental quality. The awareness of air pollution has led to numerous studies on the chemical composition of ambient aerosols and the determination of pollution sources. Atmospheric aerosols influence many atmospheric processes and have adverse human health effects, affecting both the respiratory and cardiovascular systems (Laden et al., 2000; Michael and Daniel, 2005; Ruzer and Harley, 2004; Li et al., 2009).

A major component in air urban pollution is particulate matter (PM) which can be coarse or fine. Coarse particles can be regarded as those with a diameter ranging from 2.5 to $10 \mu \mathrm{m}$ (PM2.5-10); and fine particles less than $2.5 \mu \mathrm{m}$ (PM2.5). Coarse particles usually contain materials from the earth's crust and dust from vehicles and industrial plants; while fine particles contain the secondary formed aerosols, combustion particles and re-condensed organic and metallic vapours (Jacobson, 2002).

The chemical characterization of particulate matter could be elaborated using many multi-elemental techniques. Non-destructive nuclear and related analytical techniques such as $\mathrm{X}$ ray fluorescence analysis (XRF) have already proven to be well suited for the routine analysis of aerosols samples (Chueinta et al., 2000; Biswas et al., 2003; Cohen et al., 2004; Kim Oanh et al., 2006; Santoso et al., 2008). It provides multi-element capability needed in creating databases to be used for assessing air pollution, source apportionment or time-trend assessments. This ability to quickly and efficiency produce large data sets for statistically characterizing and fingerprints pollution sources as well as estimating different source contributions is critical to the understanding of air pollution.

In Morocco, air pollution is not well estimated. The existing studies have a local character. These studies were initiated in the beginning of the 90 s by the Department of Environment in the cities which suffer significantly from atmospheric pollution (Morocco, $2000 ; 2001 ; 2002 ; 2003)$. Therefore, the present paper will present the main results of the analyses of particulate matter (coarse and fine particles) samples in Kenitra city. An evaluation of the probable sources of emission in the studied area will also be presented.

\section{MATERIAL AND METHODS}

\subsection{Sampling}

The Gent stacked filter unit sampler (Hopke et al., 1997) has been used for the collection of fine $(<2.5 \mu \mathrm{m})$ and coarse $(2.5-10 \mu \mathrm{m})$ particles on Nuclepore polycarbonate filters of 8 $\mu \mathrm{m}$ and $0.4 \mu \mathrm{m}$ pore size, respectively. Samples were collected at an average flow rate of 16 lpm for a sampling period of 24 hours. The sampler was placed near a bus station (Figure 1) located in the center of Kenitra city. There is a very high volume of motor traffic at this site, and it includes a parking for buses and many "big taxis". It is also bordered by railway. The samplers were installed in a courtyard, separated from vehicles by a wall about $3 \mathrm{~m}$ high.

Kenitra city is located about $50 \mathrm{~km}$ from Rabat (the kingdom of Morocco) and borders the Atlantic Ocean. Wind direction is predominantly West to Northwest (coming from the sea). In addition to being an important transportation hub, the city's industry is based upon the activities of its port and small businesses. The samplings were performed one day per week, from May 2007 to May 2008. A total of 126 samples (63 for fine and 63 for coarse) were taken during this period. 
TAHRI, M.; BOUNAKHLA, M.; ZGHAID, M.; NOACK, Y.; BENYAICH, F.; BENCHRIF, A. Evaluation of airborne particulate matter pollution in Kenitra City, Morocco. Ambi-Agua, Taubaté, v. 8, n. 1, p. 38-47, 2013. (http://dx.doi.org/10.4136/ambi-agua.1042)

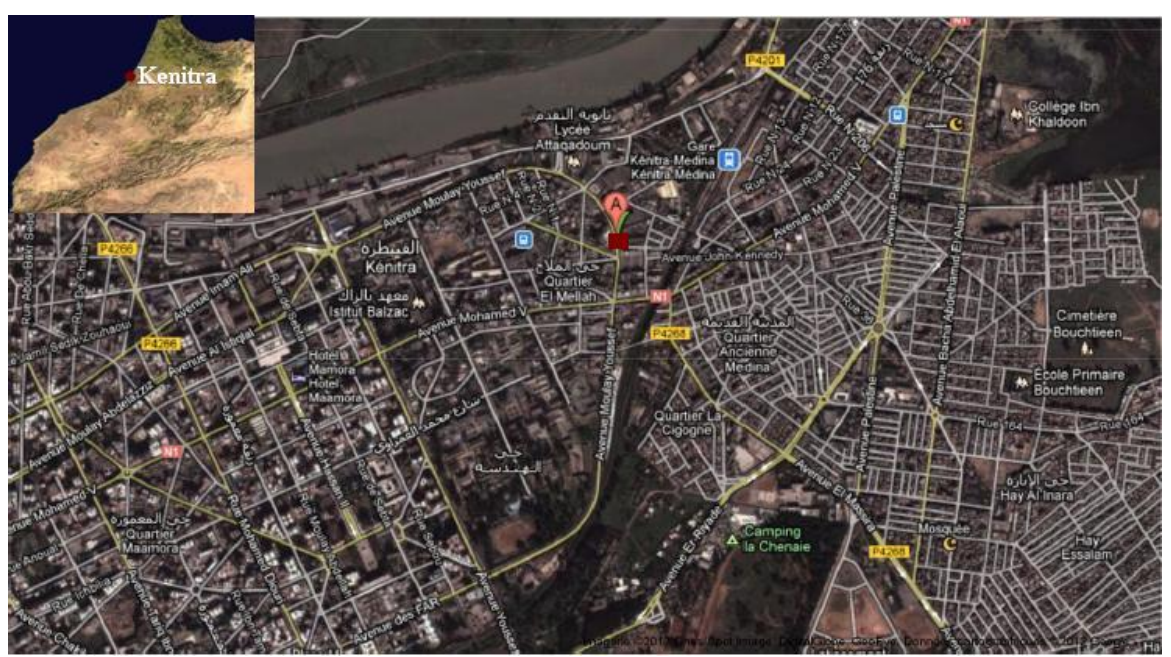

Figure 1. Location of the sampling site (noted as ' $A$ ' in the map) in Kenitra City.

\subsection{Sample Preparation and Analysis}

Multi-elemental analysis of filter samples was performed by Total X-Ray Fluorescence (TXRF). This technique needs to bring into solution the samples to be analyzed. Accordingly, the loaded filters were decomposed with $10 \mathrm{ml}$ on concentrated $\mathrm{HNO}_{3}$ in a microwave oven during time $30 \mathrm{~min}$. After decomposition and complete cooling of the solutions, $50 \mu \mathrm{g}$ of Selenium were added to each sample as internal standard, and aliquots of $25 \mu 1$ were placed onto quartz carriers for TXRF measurements.

The TXRF system employed is that installed in the National Centre of Energy, Sciences and Nuclear Techniques (CNESTEN) in Morocco. This module is equipped with a $2 \mathrm{~kW}$ power fine-focus X-ray tube with a molybdenum anode usually operating at $30 \mathrm{~mA}$ and 50 $\mathrm{kV}$. The X-ray beam is monochromatized by use of a multilayer (W/C) crystal. The fluorescent $\mathrm{X}$ - rays of the sample are detected by a $\mathrm{Si}(\mathrm{Li})$ detector with a resolution of $165 \mathrm{eV}$ at $5.9 \mathrm{keV}$ and then analyzed by a Canberra S100 multi-channel analyzer card coupled to a computer for data storage and analysis. To complete this study, we used the Atomic Absorption Spectroscopy (AAS), available in the European Centre for Research and Teaching Environmental Geosciences (CEREGE) in Aix en Provenance in France, to evaluate the contents of $\mathrm{Al}$ and $\mathrm{Na}$.

\subsection{Statistical Analysis}

Over the last two decades, multivariate analysis has been widely used to identify sources of ambient particles. In this study, Principal Component Analysis (PCA) was used to estimate and identify the possible sources of coarse and fine particles. The main objective of PCA is to reduce a large number of variables to a smaller set of factors that retain most of the information in the original data set (Hopke, 1985; Marcazzan et al., 2003). In PCA, a set of multiple correlated variables is replaced by a small number of independent variables by orthogonal transformations (Salvador et al., 2003). This transformation is achieved by diagnolizing the correlation matrix of the variables through the computation of eigenvalues and eigenvectors. Each factor explains the maximum total variance of the data set and this set is completely uncorrelated with the rest of the data. The factor concentrations obtained after the Varimax rotation gives the correlation between the variables and the factor. Thus, the chemical elements with higher concentrations in each factor are interpreted as fingerprints of emission source that it represents. In the present study, SPSS software was used to perform multivariate factor analysis. 
TAHRI, M.; BOUNAKHLA, M.; ZGHAID, M.; NOACK, Y.; BENYAICH, F.; BENCHRIF, A. Evaluation of airborne particulate matter pollution in Kenitra City, Morocco. Ambi-Agua, Taubaté, v. 8, n. 1, p. 38-47, 2013. (http://dx.doi.org/10.4136/ambi-agua.1042)

\section{RESULTS AND DISCUSSION}

\subsection{Concentration Level of Particulate Matter}

The summary of the coarse and fine particulate matter collected at the sampling site during the studied period is presented in Table 1 . The average mass concentration of coarse and fine particulates were $110.42\left(\mu \mathrm{g} \mathrm{m}^{-3}\right)$ and $50.73\left(\mu \mathrm{g} \mathrm{m}^{-3}\right)$ and the highest concentration was equal to $196\left(\mu \mathrm{g} \mathrm{m}^{-3}\right)$ and $86\left(\mu \mathrm{g} \mathrm{m}^{-3}\right)$, respectively. The time series plots of the particulates in both size particles are presented in Figures 2 and 3.

Table 1. Statistical summary of the coarse and fine particulate matter mass concentration at Kenitra city during the studied period.

\begin{tabular}{l|cc}
\hline Parameter & $\mathbf{P M}_{2.5-10}\left(\mu \mathbf{g ~ m}^{-\mathbf{3}}\right)$ & $\mathbf{P M}_{\mathbf{2 . 5}}\left(\boldsymbol{\mu} \mathbf{g ~ m}^{-\mathbf{3}}\right)$ \\
\hline Mean & 110.42 & 50.73 \\
Median & 115.12 & 51.32 \\
S.D. & 37.61 & 12.33 \\
Maximum & 195.79 & 85.68 \\
Minimum & 33.18 & 30.35 \\
$\mathrm{~N}^{\circ}$ of samples & 63 & 63 \\
\hline
\end{tabular}

The time series plot indicates that the monthly concentrations of PM2.5-10 during the winter samplings decrease significantly by half from December to January $\left(<67 \mu \mathrm{g} \mathrm{m}^{-3}\right)$, followed by a large increase at the beginning of the dry season (from 04/06/07 to 04/11/07) with concentrations ranging between 106.8 and $159.24 \mu \mathrm{g} \mathrm{m}^{-3}$. This seasonal trend could be attributed, in part, to the meteorological conditions. In fact, it was found that the higher values of PM2.5-10 correspond to higher temperatures and lower wind speed values and vice versa (Figure 2).

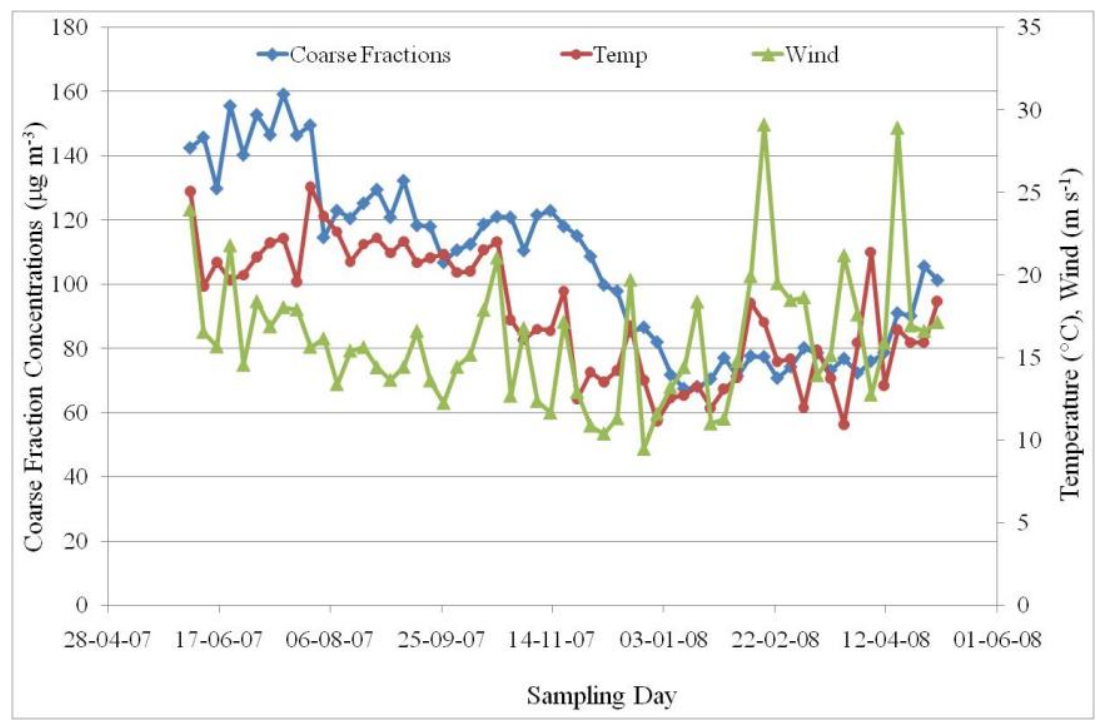

Figure 2. Variations of concentrations of coarse particulates in function of metrological parameters (wind and temperature) at Kenitra site.

However, from the beginning of the winter samplings until January, the fine particles (PM2.5) showed an inverted behaviour to that observed for coarse particles. After this period, 
TAHRI, M.; BOUNAKHLA, M.; ZGHAID, M.; NOACK, Y.; BENYAICH, F.; BENCHRIF, A. Evaluation of airborne particulate matter pollution in Kenitra City, Morocco. Ambi-Agua, Taubaté, v. 8, n. 1, p. 38-47, 2013. (http://dx.doi.org/10.4136/ambi-agua.1042)

the fine particles show a relatively stable profile with two significant peaks: the first from $10 / 06 / 2007$ to $22 / 07 / 2007$ and the second from 30/03/2008 to $11 / 05 / 2008$ with concentrations of $\left(55.83-64.18 \mu \mathrm{g} \mathrm{m}^{-3}\right.$ ) and $\left(64.34-70.47 \mu \mathrm{g} \mathrm{m}^{-3}\right)$, respectively. Nevertheless, no significant correlation was found between the concentrations of PM2.5 and the meteorological conditions as it can be observed in Figure 3.

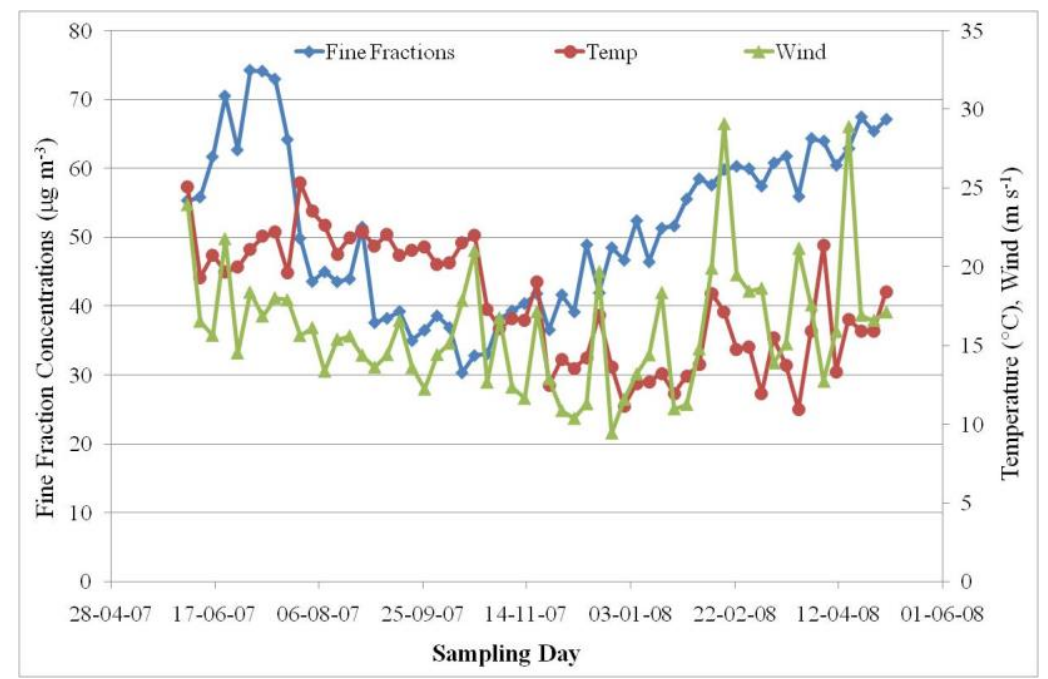

Figure 3. Variations of concentrations of fine particulates in function of meterological parameters (wind and temperature) at Kenitra site.

\subsection{Metal concentrations in particulate matter}

The results of elemental concentrations obtained for PM2.5 and PM2.5-10 and their standard deviations are presented in Table 2. The mean values presented in Table 2 are obtained from a data set of 63 samples. Twelve elements were determined for all the samples in coarse and fine particles; average concentrations of various elements range from few $\mathrm{ng} \mathrm{m}^{-3}$ (ex. Cd) to thousands of $\mathrm{ng} / \mathrm{m}^{3}$ (ex. Ca and $\mathrm{Fe}$ ).

Table 2. The mean and standard deviations of elemental concentrations of coarse and fine particulate matter at Kenitra site.

\begin{tabular}{c|rr|rc}
\hline \multirow{2}{*}{ Parameter } & \multicolumn{2}{|c|}{$\mathbf{P M}_{\mathbf{2 . 5}-\mathbf{1 0}}\left(\mathbf{n g ~ m}^{\mathbf{- 3}}\right)$} & \multicolumn{2}{c}{$\mathbf{P M}_{\mathbf{2 . 5}}\left(\mathbf{n g ~ m}^{\mathbf{- 3}}\right)$} \\
& Mean & S.D. & Mean & S.D. \\
\hline $\mathrm{Al}$ & 1848.34 & 267.48 & 140.07 & 51.19 \\
$\mathrm{Ca}$ & 11300.40 & 2016.81 & 1040.32 & 169.18 \\
$\mathrm{Cd}$ & 1.98 & 0.25 & 2.23 & 0.29 \\
$\mathrm{Cr}$ & 60.53 & 9.75 & 81.38 & 10.47 \\
$\mathrm{Cu}$ & 144.30 & 27.08 & 239.53 & 24.77 \\
$\mathrm{Fe}$ & 2051.10 & 183.07 & 1938.56 & 227.20 \\
$\mathrm{~K}$ & 1431.52 & 250.35 & 397.20 & 43.43 \\
$\mathrm{Mn}$ & 70.16 & 6.95 & 20.54 & 3.44 \\
$\mathrm{Na}$ & 2706.72 & 225.02 & 587.91 & 70.18 \\
$\mathrm{Ni}$ & 137.42 & 19.69 & 160.57 & 43.51 \\
$\mathrm{~Pb}$ & 196.04 & 29.27 & 303.22 & 64.85 \\
$\mathrm{Zn}$ & 634.01 & 68.43 & 1301.17 & 176.46 \\
\hline
\end{tabular}

* S.D. is Standard Deviation. 
Figure 4 shows a comparison of elemental concentrations in fine and coarse particles at Kenitra site. From this diagram, we can observe that, for both fine and coarse particles, $\mathrm{Cd}$ is the element with the lowest concentration; however, the highest concentration was recorded for $\mathrm{Fe}$ in fine particles and $\mathrm{Ca}$ in coarse particles. A comparison of the metal concentrations in both particles indicates that the elements of crustal origin $(\mathrm{Ca}, \mathrm{Na}, \mathrm{K}, \mathrm{Al}$ and $\mathrm{Mn})$ are more prevalent in coarse than fine particulates. However, the elements from anthropogenic sources $(\mathrm{Cd}, \mathrm{Ni}, \mathrm{Pb}, \mathrm{Cd}, \mathrm{Zn}$ and $\mathrm{Cr})$ are more prevalent in fine particulates.

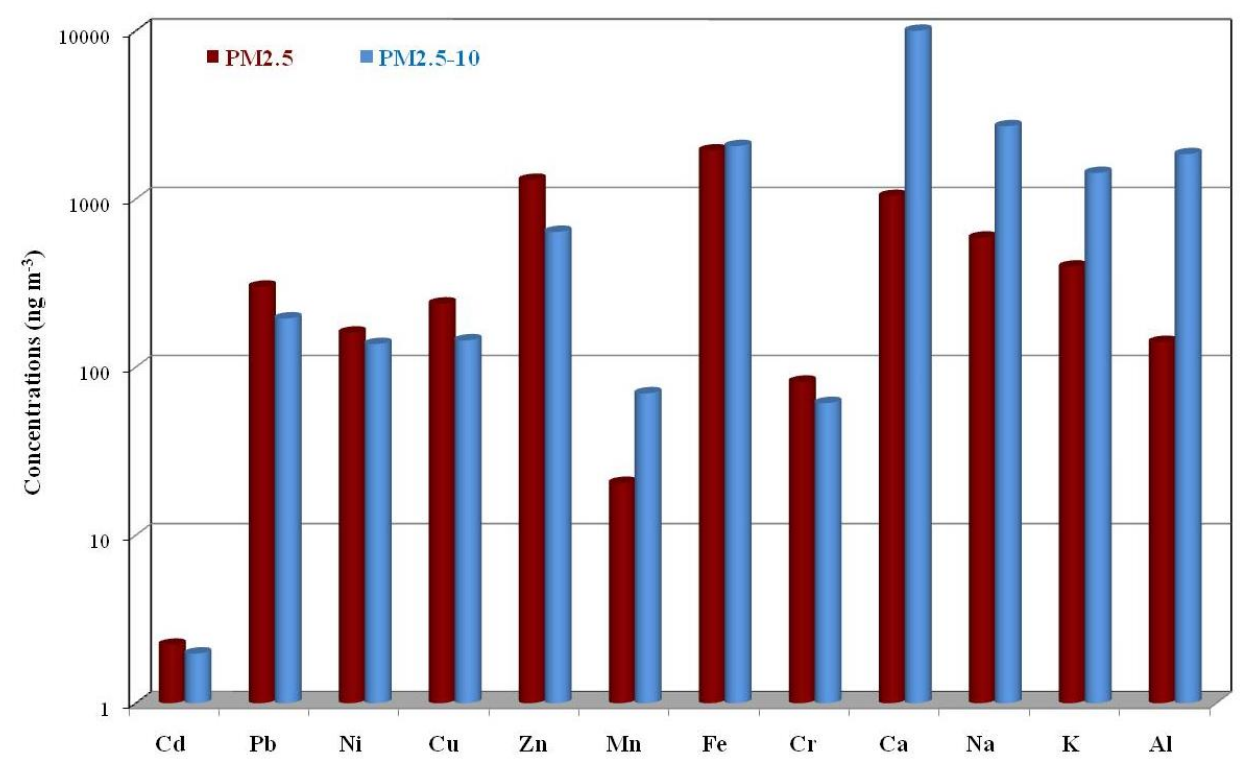

Figure 4. Comparison of metal contents in fine and coarse particles at Kenitra site.

\subsection{Multivariate analysis}

In order to get some insight about the sources of metals and the main correlations among them, Cluster Analysis (CA) and Principal Component Analysis (PCA) were applied.

The correlation matrix [63×12] gives four clusters and four significant PCs which explain $76.37 \%$ of fine particles and $80.46 \%$ of coarse particles. The obtained dendrograms are presented in Figures 5 and 6 for coarse and fine particles.

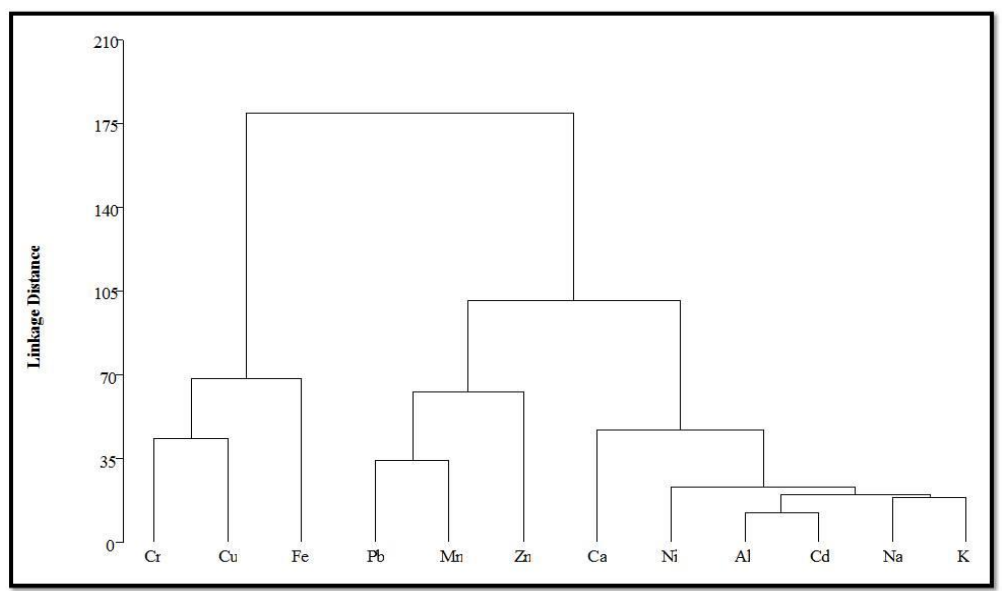

Figure 5. Dendrogram of CA of metal concentrations in coarse fraction at the studied site. 


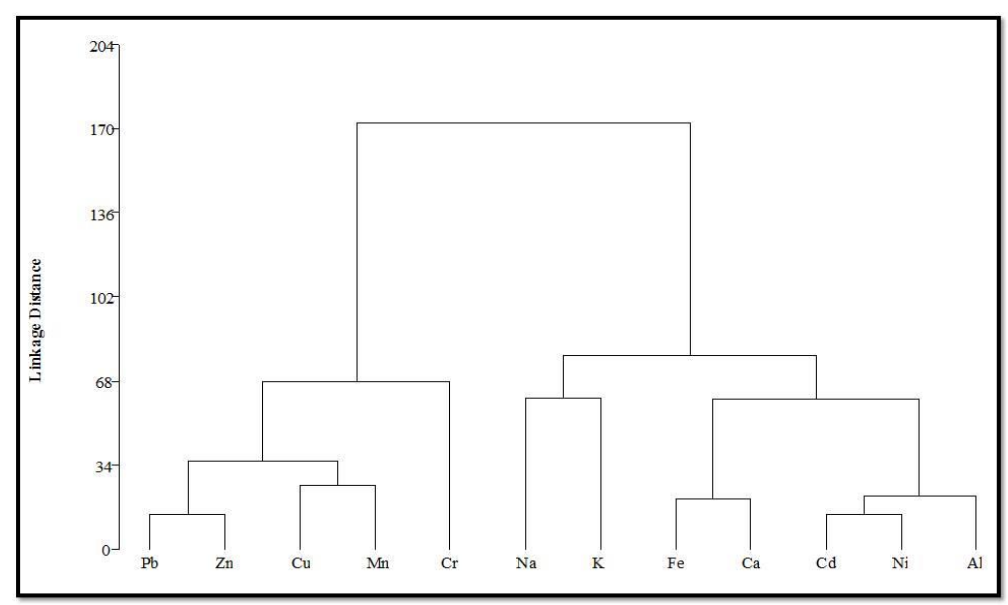

Figure 6. Dendrogram of CA of metal concentrations in fine fraction at the studied site.

The PCA results obtained by Varimax rotated factor analysis for coarse and fine particles are presented in Tables 3 and 4, respectively.

Table 3. Varimax rotated PCA factor loadings for coarse particles.

\begin{tabular}{c|cccc}
\hline Elements & Factor $\mathbf{1}$ & Factor 2 & Factor 3 & Factor 4 \\
\hline $\mathrm{Al}$ & $\mathbf{0 . 8 4}$ & 0.10 & 0.05 & -0.11 \\
$\mathrm{Ca}$ & 0.50 & -0.16 & $\mathbf{0 . 6 6}$ & -0.40 \\
$\mathrm{Cr}$ & $\mathbf{- 0 . 6 4}$ & -0.60 & 0.01 & 0.14 \\
$\mathrm{Cu}$ & -0.58 & 0.12 & $\mathbf{0 . 7 3}$ & 0.17 \\
$\mathrm{Fe}$ & 0.30 & $\mathbf{- 0 . 8 0}$ & 0.11 & -0.02 \\
$\mathrm{~Pb}$ & 0.37 & $\mathbf{0 . 6 3}$ & 0.48 & -0.12 \\
$\mathrm{Mn}$ & 0.22 & $\mathbf{0 . 7 4}$ & 0.08 & 0.32 \\
$\mathrm{Ni}$ & $\mathbf{0 . 8 2}$ & 0.27 & -0.02 & -0.02 \\
$\mathrm{Na}$ & $\mathbf{0 . 8 6}$ & -0.19 & 0.22 & 0.13 \\
$\mathrm{Cd}$ & $\mathbf{0 . 9 3}$ & 0.05 & -0.13 & -0.02 \\
$\mathrm{Zn}$ & 0.05 & 0.09 & -0.05 & $\mathbf{0 . 9 4}$ \\
$\mathrm{K}$ & $\mathbf{0 . 8 6}$ & 0.06 & 0.10 & 0.12 \\
\hline
\end{tabular}

Factor 1 of PCA results of PM2.5-10 (Table 3) show higher concentrations for Al, Cr, $\mathrm{Ni}, \mathrm{Na}, \mathrm{Cd}$ and $\mathrm{K}$ with the maximum percentage of variance $(41.84 \%)$. This factor represents a mixture of natural soil dust ( $\mathrm{Al}, \mathrm{Na}$ and $\mathrm{K}$ ) and anthropogenic dust $(\mathrm{Cr}, \mathrm{Ni}, \mathrm{Cd})$. Therefore, Factor 1 could be assigned to the re-suspension of soil dust contaminated by traffic road. Factor 2 explains $17.48 \%$ of the total variance and shows high loadings for Fe $(-0.79)$, Mn (0.74) and $\mathrm{Pb}(0.63)$, indicating emissions of road soil dust. The third factor accounts for $10.7 \%$ of the total variance. The dominant elements of this factor are $\mathrm{Ca}$ and $\mathrm{Cu}$ with a PC concentrations of 0.66 and 0.73 , respectively, representing soil dust origins. The last factor explains $10.44 \%$ of the total variance. The only dominant element for this factor is $\mathrm{Zn}$ with a PC concentrations of 0.94 which indicates traffic emission such as breakdown abrasion. 
TAHRI, M.; BOUNAKHLA, M.; ZGHAID, M.; NOACK, Y.; BENYAICH, F.; BENCHRIF, A. Evaluation of airborne particulate matter pollution in Kenitra City, Morocco. Ambi-Agua, Taubaté, v. 8, n. 1, p. 38-47, 2013. (http://dx.doi.org/10.4136/ambi-agua.1042)

Table 4. Varimax rotated PCA factor loadings for fine particles.

\begin{tabular}{c|cccc}
\hline Elements & Factor $\mathbf{1}$ & Factor 2 & Factor 3 & Factor 4 \\
\hline $\mathrm{Cd}$ & 0.03 & $\mathbf{0 . 7 6}$ & 0.53 & 0.05 \\
$\mathrm{~Pb}$ & $\mathbf{0 . 8 6}$ & 0.03 & 0.21 & -0.33 \\
$\mathrm{Ni}$ & 0.32 & $\mathbf{0 . 6 7}$ & 0.50 & -0.20 \\
$\mathrm{Cu}$ & $\mathbf{0 . 8 5}$ & -0.07 & -0.08 & 0.25 \\
$\mathrm{Zn}$ & $\mathbf{0 . 8 8}$ & 0.13 & 0.12 & -0.08 \\
$\mathrm{Mn}$ & $\mathbf{0 . 7 2}$ & 0.12 & -0.36 & 0.06 \\
$\mathrm{Fe}$ & 0.17 & $\mathbf{0 . 8 5}$ & -0.16 & 0.04 \\
$\mathrm{Cr}$ & 0.22 & -0.09 & $\mathbf{- 0 . 7 7}$ & 0.05 \\
$\mathrm{Ca}$ & 0.06 & $\mathbf{0 . 7 7}$ & -0.13 & 0.43 \\
$\mathrm{Na}$ & -0.04 & 0.05 & 0.18 & $\mathbf{0 . 9 0}$ \\
$\mathrm{K}$ & 0.15 & 0.04 & $\mathbf{0 . 6 2}$ & 0.16 \\
$\mathrm{Al}$ & -0.28 & $\mathbf{0 . 7 3}$ & 0.35 & -0.22 \\
\hline
\end{tabular}

PCA of fine particulate matter identified four factors with the total variance of 76.37 . Factor 1 has high concentrations of $\mathrm{Pb}(0.86), \mathrm{Cu}(0.85), \mathrm{Zn}(0.88)$ and $\mathrm{Mn}(0.72)$ which explains $25.40 \%$ of the total variance. This factor is associated with elements from traffic emission sources (Veron et al., 1992; Manoli et al., 2002; Samara and Voutsa, 2005; Chang et al., 2009). Thus, factor 1 could be identified as traffic emissions. Factor 2 accounts for $24.41 \%$ of the total variance. This factor is a mixture of soil dust (Fe, $\mathrm{Ca}$ and $\mathrm{Al})$ and traffic emissions or road dust $(\mathrm{Cd}$ and $\mathrm{Ni})$. Therefore, factor 2 could be interpreted as soil/road dust. Factor 3, with $15.79 \%$ of the total variance, includes high concentrations for $\mathrm{K}(0.62)$ and $\mathrm{Cr}$ (-0.77) indicating soil dust origin (Lee and Thi Hieu, 2011). Factor 4 accounts for $10.77 \%$ of the total variance. The only dominant element for this factor is $\mathrm{Na}$ with a high concentration of 0.79 which clearly indicates its origin from sea salt.

\section{CONCLUSIONS}

Airborne particulate matter in two size particles PM2.5-10 and PM2.5 collected at Kenitra City (Morocco) have been analyzed for chemical composition using TXRF and AAS. Time series analysis of particulate matter revealed a seasonal trend with high concentrations during summer period. The contents of chemical elements indicated that $\mathrm{Cd}$ is the element that showed the lowest concentrations for both particles. However, Ca presented the highest concentrations in coarse particles and Fe the highest values in the fine particles. Using the principal component, four factors were obtained for both particles. The identified sources for fine and coarse particulates were approximately similar and were mainly related to soil dust and traffic emissions. 


\section{REFERENCES}

BISWAS, S. K.; TARAFDAR, S. A.; ISLAM, A.; KHALIQUZZAMAN, M.; TERVAHATTU, H.; KUPIAINEN, K. Impact of unleaded gasoline introduction on the concentration of lead in the air of Dhaka, Bangladesh. Journal of Air and Waste Management Association, v. 53, p. 1355-1362, 2003. http://dx.doi.org/ 10.1080/ 10473289.2003.10466299

CHANG, S. H.; WANG, K. S.; CHANG, H. F.; NI, W. W.; WU, B. J.; WONG, R. H. et al. Comparison of source identification of metals in road-dust and soil. Soil Sediment Contamination, v. 18, p. 669-683, 2009. http://dx.doi.org/10.1080/1532038090 3085691

CHUEINTA, W.; HOPKE, P. K.; PAATERO, P. Investigation of sources of atmospheric aerosol at urban and suburban residential areas in Thailand by positive matrix factorization. Atmospheric Environment, v. 34, p. 3319-3329, 2000. http://dx. doi.org/10.1016/S1352-2310(99)00433-1

COHEN, D. D; GORTON, D.; STELCER, E.; HAWAS, O. Accelerator based studies of atmospheric pollution processes. Radiation Physics and Chemistry, v. 71, p. 759-767, 2004. http://dx.doi.org/10.1016/j.radphyschem.2004.04.123

HOPKE, P. K.; XIE, Y.; RAUNEMAA, T.; BIEGALSKI, S.; LANDSBERGER, S.; MAENHAUT, W.; ARTAXO, P. et al. Characterization of the Gent Stacked Filter Unit PM10 Sampler. Aerosol Science and Technology, v. 27, p. 726-735, 1997. http://dx. doi.org/10.1080/02786829708965507

HOPKE, P. K. Receptor modeling in environmental chemistry. New York: John Wiley \& Sons, 1985.

JACOBSON, M. Z. Atmospheric pollution: history, science and regulation. New York: Cambridge University Press, 2002.

KIM OANH, N. T.; UPADHAYAY, N.; ZHUANG, Y. H.; HAO, Z. P.; MURTHY, D. V. S; LESTARI, P. et al. Particulate air pollution in six Asian cities: spatial and temporal distributions, and associated sources. Atmospheric Environment, v. 40, p. 3367-3380, 2006. http://dx.doi.org/10.1016/j.atmosenv.2006.01.050

LADEN, F.; NEAS, L. M.; DOCKERY, D. W.; SCHWARTZ, J. Association of fine particulate matter from different sources with daily mortality in six U.S. cities. Environment Health Persectives, v. 108, p. 941-947, 2000. http://dx.doi.org/ $10.2307 / 3435052$

LEE, B. K.; THI HIEU, N. Seasonal variation and sources of heavy metals in atmospheric aerosols in a residential area of Ulsan, Korea. Aerosol and Air Quality Research, v. 11, p. 679-688, 2011. http://dx.doi.org/10.4209/aaqr.2010.10.0089

LI, W.; BAI, Z.; LIU, A.; CHEN, J.; CHEN, L. Characteristics for major PM2.5 components during winter in Tianjin, China. Aerosol Air Quality Research, v. 9, p. 105-119, 2009.

MANOLI, E.; VOUTSA, D.; SAMARA, C. Chemical characterization and source identification/apportionment of fine and coarse air particles in Thessaloniki, Greece. Atmospheric Environment, v. 36, p. 949-961, 2002. http://dx.doi.org/10.1016/S13522310(01)00486-1 
TAHRI, M.; BOUNAKHLA, M.; ZGHAID, M.; NOACK, Y.; BENYAICH, F.; BENCHRIF, A. Evaluation of airborne particulate matter pollution in Kenitra City, Morocco. Ambi-Agua, Taubaté, v. 8, n. 1, p. 38-47, 2013. (http://dx.doi.org/10.4136/ambi-agua.1042)

MARCAZZAN, G. M.; CERIANI, M.; VALLI, G.; VECCHI, R. Source apportionment of PM10 and PM2.5 in Milan (Italy) using receptor models. Science Environment, v. 317, p. 137-147, 2003. http://dx.doi.org/10.1016/S0048-9697(03)00368-1

MOROCCO. Ministry of Territorial, Urban, Housing and Environment Planning and Ministry of Health. Casa-Airpol: study of air pollution and its impact on population health in Casablanca City, Campaigns of 1998-1999. Rabat, 2000.

MOROCCO. Ministry of Territorial, Urban, Housing and Environment Planning and Ministry of Health. Mohammedia-airpol: Study of air pollution and its impact on the health of asthmatic children in Mohammedia City, 2001-2002 campaigns. Rabat, 2002.

MOROCCO. Ministry of Territorial, Urban, Housing and Environment Planning and Ministry of Health. Report on the state of the environment of Morocco - REEM. Rabat, 2001.

MOROCCO. Ministry of Territorial, Water and Environment Planning, Department of the Air and National Laboratory of Environment, Department of Surveillance and Prevention Risks - MATEE. Air pollution in Morocco, Situation in 2002. Rabat, 2003.

MICHAEL, F. W.; DANIEL, L. C. Air pollution and the respiratory tract. 2. ed. Boca Raton: Taylor and Francis, 2005.

RUZER, L. S.; HARLEY, N. H. Aerosols handbook: measurement dosimetry and health effects. [S.1.]: CRC Press, 2004.

SALVADOR, P.; ARTINANO, B.; DIANA, G. A.; XAVIER, Q.; ANDRES, A. Identification and Characterization of Sources of $\mathrm{PM}_{10}$ in Madrid (Spain) by statistical methods. Atmospheric Environment, v. 38, p. 435-447, 2003. http://dx.doi.org/10.1016/j. atmosenv.2003.09.070

SAMARA, C.; VOUTSA, D. Size distribution of airborne particulate matter and associated heavy metals in the roadside environment. Chemosphere, v. 59, p. 1197-1206, 2005. http://dx.doi.org/10.1016/j.chemosphere.2004.11.061

SANTOSO, M.; HOPKE, P. K.; HIDAYAT, A.; DWIANA, D. Sources identification of atmospheric aerosol at urban and suburban sites in Indonesia by positive matrix factorization. Science of Total Environment, v. 397, 229-237, 2008. http://dx.doi. org/10.1016/j.scitotenv.2008.01.057

VERON, A.; CHURCH, T. M.; PATTERSON, C. C.; EREL, Y.; MERRILL, J. T. Continental Origin and Industrial Sources of Trace Metals in the Northwest Atlantic Troposphere. Journal of Atmospheric Chemistry, v. 14, p. 339-351, 1992. http://dx.doi.org/10.1007/BF00115243 